\title{
A TEN-YEAR BIOMONITORING STUDY OF ATMOSPHERIC DEPOSITION OF TRACE ELEMENTS AT THE TERRITORY OF THE REPUBLIC OF BELARUS
}

\author{
10-LETNIE BADANIA BIOMONITORINGOWE DEPOZYCJI \\ PIERWIASTKÓW ŚLADOWYCH DO ATMOSFERY \\ NA TERENIE REPUBLIKI BIALORUSI
}

\begin{abstract}
For the third time since 2005 atmospheric deposition of trace elements in Belarus was monitored by the moss technique widely used in Europe for air pollution studies. Samples of moss species of Hylocomium splendens and Pleurozium schreberi were collected at 86 sites over the Gomel, Vitebsk and Minsk Regions in the summer of 2015. A total of 30 elements were determined by epithermal neutron activation analysis. Studying of the temporal trends in Belarus was undertaken with the results obtained in previous moss surveys in 2005/2006 and 2010/2011. Comparison with the analogous data from the neighbouring countries showed relatively low contamination levels in Belarus for the most heavy and toxic elements. The results of survey 2010/2011 showed that, except $\mathrm{Cr}$, other element concentrations reduce or are at the same levels.
\end{abstract}

Keywords: air pollution, moss biomonitoring, Republic of Belarus, trace metals, neutron activation analysis

\section{Introduction}

The usual way to study atmospheric deposition of heavy metals and some toxic elements is precipitation analysis. Alternative way for such kind of research is using of terrestrial mosses as biomonitors.

Moss is the most effective type of organism for biomonitoring of metals from the atmosphere because of its ability to accumulate and retain chemical substances, including trace elements. Mosses have only a rudimentary root system, so the uptake of elements comes mostly from the atmosphere. Another advantage is the easiest way of collecting mosses than precipitation. The moss biomonitoring technique is widely used all over the Europe as a method to evaluate atmospheric deposition of metals more than 30 years $[1,2]$.

This programme was established in 1987 to consider the underlying science for quantifying damage to plants by ozone and other air pollutants. In 2001, the ICP Vegetation expanded its research area to included heavy metal deposition from the atmosphere. Over

\footnotetext{
${ }^{1}$ Joint Institute for Nuclear Research, Joliot-Curie Str. 6, 141980 Dubna, Russia, phone +7-4962163676, fax+7-4962165085, email: beataa@gmail.com, marina@nf.jinr.ru

*Corresponding author: beataa@gmail.com
} 
200 scientists from 35 countries participate in the ICP Vegetation Programme [2-4]. The results of this study were gathered by the Coordination Center of the International Cooperative Programme on Effects of Air Pollution on Natural Vegetation and Crops (ICP Vegetation).

In 2005 the Republic of Belarus was involved in the UNECE ICP Vegetation Programme and for the first time the atmospheric deposition of trace elements was studied over the entire territory of the Republic of Belarus using samples of terrestrial mosses.

Before this research heavy metals were determined only in soils [5] and few elements are determined in air in cities according to governmental annual monitoring reports [5]. Our research was done to cover one more "white spot" on the heavy metal atmospheric deposition map of Europe.

Expected results:

- creation of a database for continued studies at regular intervals;

- comparison of the environmental contamination levels in parts of Belarus with other areas in Europe;

- determination of the polluted areas in Belarus and sources of pollution.

\section{Material and methods}

\section{Study area}

Belarus occupies an area of 207600 square kilometres. The longest distance from west to east is $650 \mathrm{~km}$, from north to south $560 \mathrm{~km}$. The terrain of Belarus is predominantly plain with hills: the average elevation is $160 \mathrm{~m}$ above the sea level; the highest elevation is $345 \mathrm{~m}$. Its neighbours are Russia to the east and northeast, Latvia to the north, Lithuania to the northwest, Poland to the west, and Ukraine to the south.

The inalienable part of Belarusian landscape is bogs and swamps, which cover about 13 per cent of the total area and have a large climatic and hydrological significance. About three-fifths of Belarus is covered by podzolic soils, also there are turf-podzol sand and peat-boggy soils. Agricultural land occupies $43.9 \%$ of the country's area, including $26.5 \%$ of arable land. Belarus lies in the zone of mixed forest, which occupies $37.8 \%$ of the country's area.

In the sampled area are well-developed: the machine-building industry (mechanical engineering, machine-building, automobile production, metallurgy, tractor and agricultural machinery production), electronic industry (electronic, radiotechnical, electrotechnical, optico-mechanicle and instrument-construction branches), fuel, chemical and petrochemical industries. Also very important role plays wood, wood-pulp and paper industry, construction materials production, light and food industries.

\section{Sampling}

Samples of the two moss species Pleurozium schreberi ((Brid.) Mitt.) (more than $85 \%$ of all collected samples) and Hylocomium splendens ((Hedw.) Schimp) were collected during 2005-2015 years in all country regions. Sampling sites were located at least $300 \mathrm{~m}$ from main roads and populated areas and at least $100 \mathrm{~m}$ from smaller roads. From each sampling site, 5 to 10 sub-samples were taken within a $50 \times 50 \mathrm{~m}$ area and mixed in the field. Sampling and sample handling was performed using polyethylene gloves and collected material was stored in paper bags [6].

The sampling network is shown in Figure 1. 


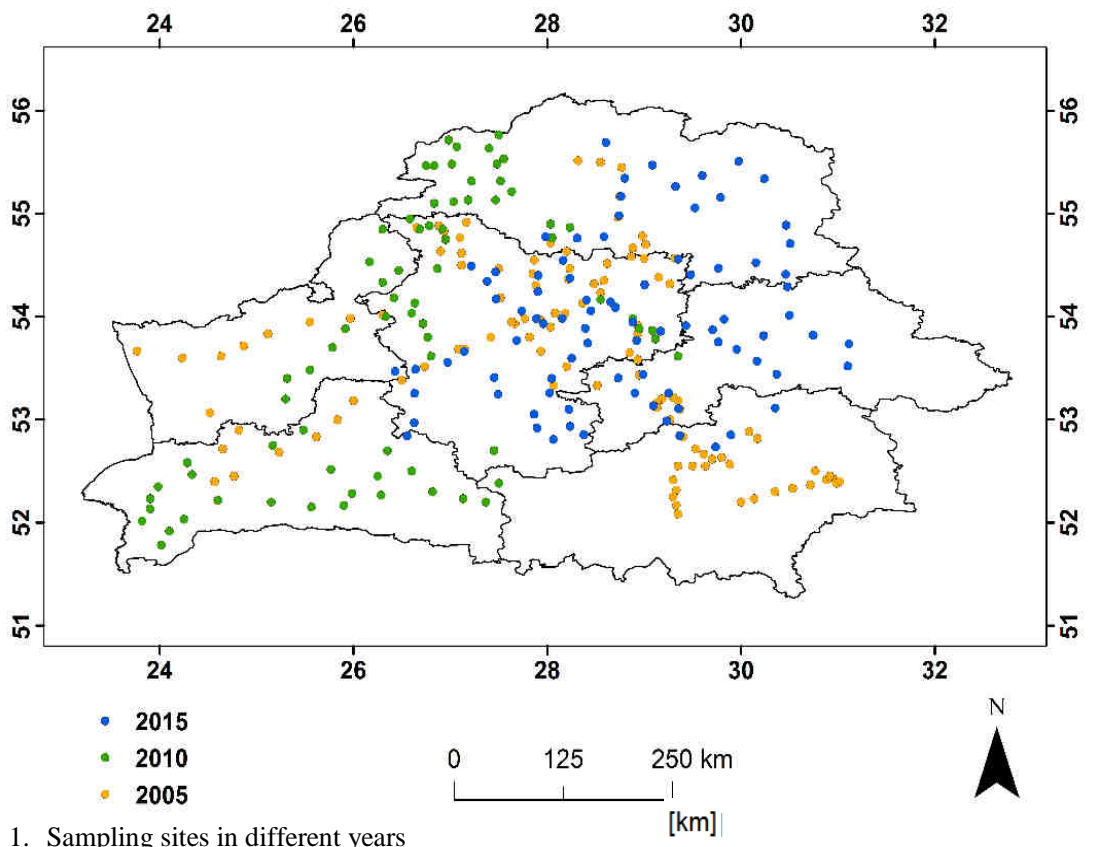

Fig. 1. Sampling sites in different years

\section{Analysis}

The neutron activation analysis allowed determining a total of 30 elements. Epithermal neutron activation analysis (ENAA) [7, 8] was performed in the Frank Laboratory of Neutron Physics (Dubna, Russia).The samples were carefully cleaned from needles, leaves, soil particles and only the green, green-brown shoots representing the last three years growth were analyzed, after being air-dried to constant weight at $30-40{ }^{\circ} \mathrm{C}$ for 48 hours. The samples were neither washed nor homogenized. Previous surveys based on NAA in moss biomonitoring have shown that samples of about $300 \mathrm{mg}$ are large enough to be used without homogenization [7].

For the short-term irradiation, samples of about $300 \mathrm{mg}$ were palletized in simple press-forms and heat-sealed in polyethylene foil. For the long-term irradiation, samples were prepared in the same manner and packed in aluminum cups.

The samples were irradiated in the IBR-2 fast-pulsed reactor, in channels equipped with a pneumatic system. The average thermal neutron flux density at the moderator surface was $10^{13}$ neutrons $\mathrm{cm}^{2} \mathrm{~s}^{-1}$.

Two kinds of analyses were performed: to determine short-lived radionuclides $(\mathrm{Ca}, \mathrm{Cl}$, $\mathrm{I}, \mathrm{Mg}, \mathrm{Mn}, \mathrm{V})$ the samples were irradiated for 3 minutes in the second channel (Ch2) and to determine elements associated with long-lived radionuclides ( $\mathrm{Na}, \mathrm{K}, \mathrm{Sc}, \mathrm{Cr}, \mathrm{Fe}, \mathrm{Co}, \mathrm{Ni}, \mathrm{Zn}$, As, Br, Se, Rb, Mo, Sb, Cs, Ba, La, Hf, W, Th, U) samples were irradiated for 100 hours in the cadmium-screened Ch1.

After short irradiation samples were measured for 15 minutes using Canberra HPGe detectors (relative efficiency 40-55\%, resolution $1.85 \mathrm{keV}$ ). In case of long irradiation, samples were repacked into clean containers and measured after 4-5 days for 30 minutes and after 20-23 days for 90 minutes. 
The content of $\mathrm{Cd}, \mathrm{Cu}$, and $\mathrm{Pb}$ in the moss samples in 2005/2006 moss survey was determined by AAS [9].

\section{Quality control (QC)}

The QC of NAA results were ensured by analysis of reference materials: trace and minor elements in lichen IAEA-336 (International Atomic Energy Agency), IAEA-SL-1 (Trace elements in lake sediment), SRM 2710 (Montana Soil), SRM 1632b (Trace Elements in Coal (Bituminous)) and SRM-1633b (Constituent elements in coal fly ash, US NIST-National Institute of Standards and Technology). The reference materials were irradiated under the same conditions as samples.

\section{Results and discussion}

Part of the results presented in the given paper was published in the European Atlas of Heavy Metal Atmospheric Deposition issued by UNECE ICP Vegetation [2, 3].

In Table 1 median values $(\mathrm{Md})$ and ranges for the contents of all elements were compared with the data obtained in the 2005/2006 moss survey in the Republic of Belarus [9] and corresponding data from similar studies in the neighboring countries: Russian Federation (Central region), Poland (Opole region) [10], Latvia, Lithuania and Ukraine [2]. For comparison with a pristine territory, data for northern Norway [11] are shown.

Comparison of the median values for $\mathrm{V}, \mathrm{Cr}, \mathrm{Fe}, \mathrm{Ni}, \mathrm{Zn}, \mathrm{As}, \mathrm{Al}, \mathrm{Sb}$ from the three surveys in Belarus (in 2005/2006, 2010/2011 and 2015), showed a decrease of the content of $\mathrm{V}$ and As in the mosses and increase of $\mathrm{Cr}$ in 2010 (Fig. 2a,b). Other elements are mostly at the same levels. These results are in respond with the reported data by Harmens et al. [12]. It was shown that between moss surveys in 2005 and 2010 Europe-wide decline for some elements were found but still country and region-specific temporal trends were observed. Decrease of elements concentration in moss could be explained by declined emissions of heavy metals across Europe in recent years [13].

Ranking the countries round Belarus (Latvia, Lithuania, Poland, Russia and Ukraine) according to the median values for each element showed that median values for almost all elements reported in Atlas are low for Belarus. The highest medians for $\mathrm{Cr}, \mathrm{Fe}, \mathrm{Zn}$, As were observed in Poland what came as no surprise because Polish data are from the industrial region. For Lithuania were observed higher medians for $\mathrm{V}$ and $\mathrm{Pb}$, and for Ukraine the median values were higher for $\mathrm{Ni}, \mathrm{Cu}$ and $\mathrm{Cd}$. In comparison with the pristine northern Norway, however, the Belarusian data are higher for typical air pollution elements $(\mathrm{V}, \mathrm{Cr}$, $\mathrm{Ni}, \mathrm{Cu}, \mathrm{Zn}, \mathrm{As}, \mathrm{Cd}, \mathrm{Sb}$, and $\mathrm{Pb}$ ). In the case of $\mathrm{Ca}, \mathrm{Br}, \mathrm{I}, \mathrm{Sr}$ and Mo the situation is the opposite. Lower $\mathrm{Ca}$, Sr, Mo median could be explained by the local micro-environment and the lower median for $\mathrm{Br}$ and I are explained by the fact that Belarus is a landlocked country with lower marine influence than Norway [11]. The Norwegian data are also much lower for the elements that have been previously described mainly to soil particles attached to the moss (Sc, Fe, rare-earth elements, Th, and U). The differences in the results could be explained by the difference in the methods applied for the analysis. In non-destructive NAA the whole amount of the elements in sample are analysed. Data from northern Norway are obtained by ICP-MS analysis [14]. The analysis with ICP-MS as well as AAS is based on acid digestion, potentially leaving out a fraction of the elements due to their refractory minerals [15]. 
a)

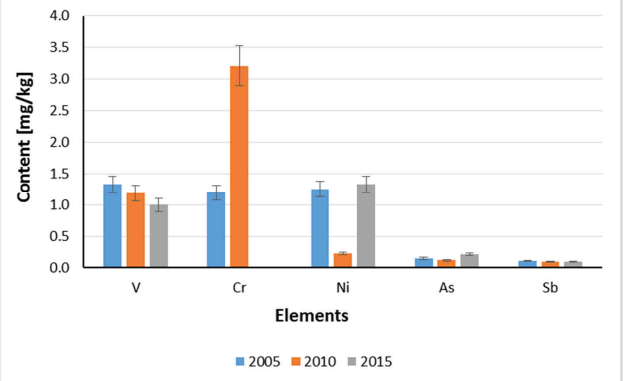

b)

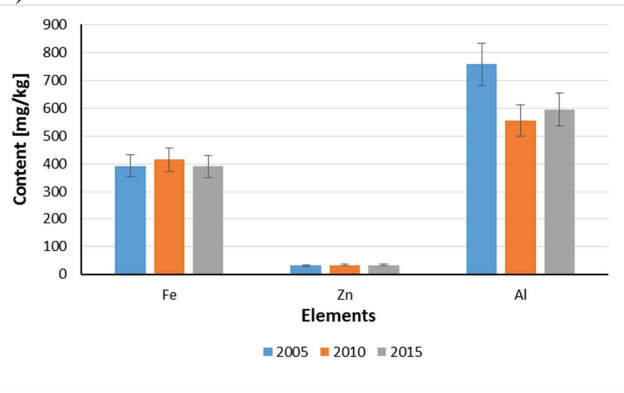

Fig. 2. Comparison of the median concentrations for selected elements determined in 2005, 2010 and 2015: a) V, Cr, Ni, As, Sb; b) Fe, Zn, Al

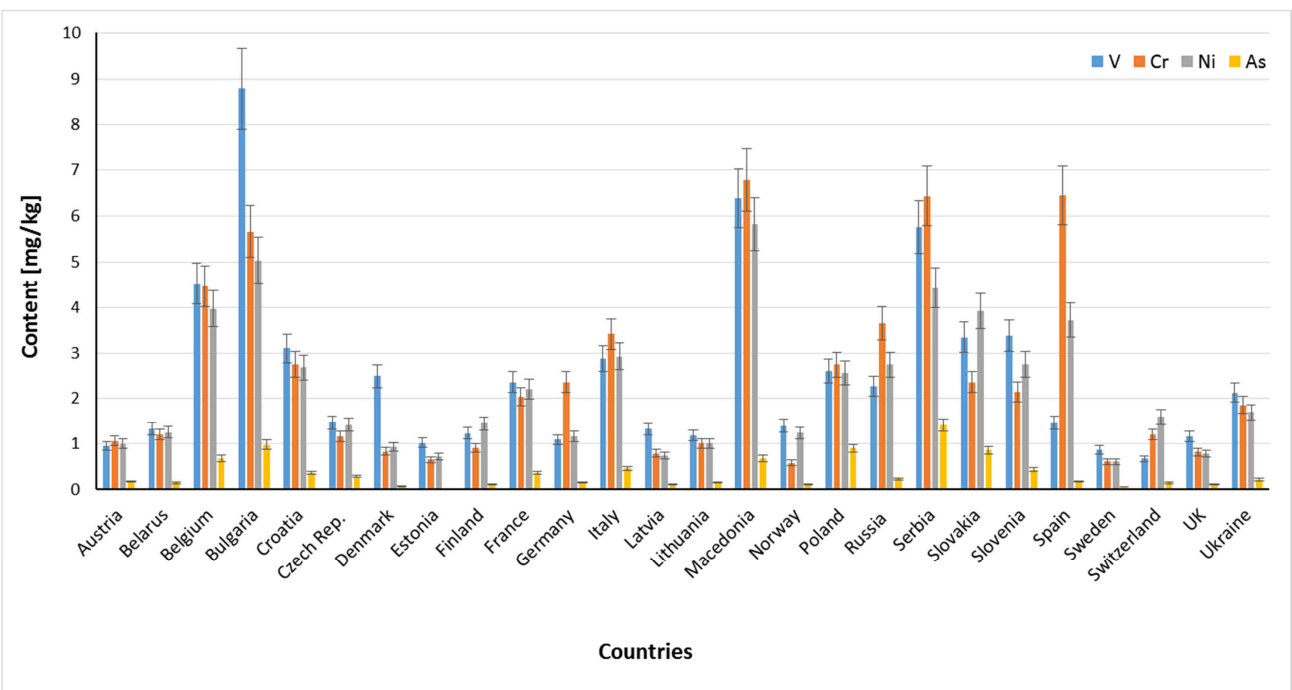

Fig. 3. Median concentrations for V, Cr, Ni, As, data from European Atlas - 2005/2006

Table 1

Comparison of the results obtained in moss survey 2005/2006 with neighbouring countries and Norway for different elements concentrations $[\mathrm{mg} / \mathrm{kg}]$

\begin{tabular}{|c|c|c|c|c|c|c|c|c|}
\hline \multirow{2}{*}{ Element } & \multicolumn{2}{|c|}{ Belarus [9] } & \multicolumn{2}{c|}{ Poland [10] } & \multicolumn{2}{c|}{ Northern Norway [11] } & \multicolumn{2}{c|}{ Latvia [2] } \\
\cline { 2 - 9 } & Md & Range & Md & Range & Md & Range & Md & Range \\
\hline $\mathbf{N a}$ & 147 & $74-537$ & 198 & $82-536$ & - & - & - & - \\
\hline $\mathbf{C l}$ & 188 & $55-828$ & 462 & $161-1045$ & - & - & - & - \\
\hline $\mathbf{K}$ & 3849 & $1529-30070$ & 8352 & $5740-17260$ & - & - & - & - \\
\hline $\mathbf{C a}$ & 2729 & $1416-7375$ & 4870 & $2785-11660$ & 2820 & $1680-5490$ & - & - \\
\hline $\mathbf{S c}$ & 0.11 & $0.03-0.77$ & 0.23 & $0.08-1.14$ & 0.052 & $0.009-0.220$ & - & - \\
\hline $\mathbf{V}$ & 1.33 & $0.40-9.57$ & 2.8 & $1.1-11.7$ & 0.92 & $0.39-5.10$ & 1.8 & $0.6-23.0$ \\
\hline $\mathbf{C r}$ & 1.2 & $0.18-11.61$ & 2.8 & $1.5-9.1$ & 0.55 & $0.10-4.20$ & 0.95 & $0.58-3.30$ \\
\hline $\mathbf{M n}$ & 403 & $43.47-1852$ & 236 & $37-882$ & 256 & $22-750$ & - & - \\
\hline $\mathbf{F e}$ & 394 & $166-2243$ & 813 & $240-3086$ & 209 & $77-1370$ & 134 & $80-392$ \\
\hline $\mathbf{C o}$ & 0.25 & $0.11-7.02$ & 0.5 & $0.2-1.1$ & 0.202 & $0.065-0.654$ & - & - \\
\hline
\end{tabular}




\begin{tabular}{|c|c|c|c|c|c|c|c|c|}
\hline \multirow{2}{*}{ Element } & \multicolumn{2}{|c|}{ Belarus [9] } & \multicolumn{2}{c|}{ Poland [10] } & \multicolumn{2}{c|}{ Northern Norway [11] } & \multicolumn{2}{c|}{ Latvia [2] } \\
\cline { 2 - 9 } & Md & Range & Md & Range & Md & Range & Md & Range \\
\hline $\mathbf{N i}$ & 1.25 & $0.55-5.65$ & 2.0 & $0.8-4.9$ & 1.10 & $0.10-6.60$ & 0.98 & $0.50-5.50$ \\
\hline $\mathbf{C u}$ & 4.40 & $3.1-7.3$ & - & - & 3.60 & $2.1-9.2$ & 5.1 & $3.1-12.7$ \\
\hline $\mathbf{Z n}$ & 31.3 & $17.6-65.1$ & 64 & $26-125$ & 26.50 & $8-173$ & 31 & $20-189$ \\
\hline $\mathbf{A s}$ & 0.15 & $0.05-0.49$ & 0.89 & $0.30-3.12$ & 0.093 & $0.02-0.51$ & 0.060 & $0.001-0.180$ \\
\hline $\mathbf{S e}$ & 0.71 & $0.09-1.89$ & 0.24 & $0.07-0.61$ & 0.33 & $0.05-1.30$ & - & - \\
\hline $\mathbf{B r}$ & 1.30 & $0.48-3.50$ & 2.4 & $1.0-5.0$ & 4.50 & $1.4-20.3$ & - & - \\
\hline $\mathbf{R b}$ & 20.9 & $5.9-55.2$ & 21 & $9--37$ & 7.70 & $1.3-51.5$ & - & - \\
\hline $\mathbf{S r}$ & 9.2 & $3.7-65.9$ & 22 & $12--54$ & 15.80 & $3.6-43.3$ & - & - \\
\hline $\mathbf{M o}$ & 0.099 & $0.038-0.650$ & 0.22 & $0.06-0.53$ & 0.135 & $0.065-0.700$ & - & - \\
\hline $\mathbf{C d}$ & 0.215 & $0.10-0.66$ & - & - & 0.058 & $0.025-0.171$ & 0.16 & $0.10-2.10$ \\
\hline $\mathbf{S b}$ & 0.11 & $0.04-0.23$ & 0.36 & $0.13-0.68$ & 0.033 & $0.004-0.240$ & - & - \\
\hline $\mathbf{I}$ & 0.67 & $0.19-1.65$ & 1.4 & $0.4-5.4$ & 2.50 & $0.6-41.7$ & - & - \\
\hline $\mathbf{C s}$ & 0.21 & $0,06-1.22$ & 0.45 & $0.12-1.25$ & 0.072 & $0.016-0.880$ & - & - \\
\hline $\mathbf{B a}$ & 19.9 & $7.2-90.3$ & 42 & $12--97$ & 17.10 & $5.60-50.50$ & - & - \\
\hline $\mathbf{L a}$ & 0.46 & $0.20-3.78$ & 0.88 & $0.46-4.32$ & 0.189 & $0.045-2.560$ & - & - \\
\hline $\mathbf{C e}$ & 0.93 & $0.12-8.71$ & 1.90 & $0.9-9.3$ & 0.342 & $0.095-4.610$ & - & - \\
\hline $\mathbf{W}$ & 0.45 & $0.07-1.46$ & 0.20 & $0.14-0.65$ & 0.13 & $0.01-1.23$ & - & - \\
\hline $\mathbf{P b}$ & 3.52 & $1.46-5.61$ & - & - & 1.17 & $0.64-6.12$ & 2.9 & $1.5-37.0$ \\
\hline Th & 0.11 & $0.03-1.00$ & 0.22 & $0.06-1.30$ & 0.033 & $0.004-0.240$ & - & - \\
\hline $\mathbf{U}$ & 0.05 & $0.01-0.41$ & 0.10 & $0.02-0.51$ & 0.015 & $0.001-0.138$ & - & - \\
\hline
\end{tabular}

\begin{tabular}{|c|c|c|c|c|c|c|}
\hline \multirow{2}{*}{ Element } & \multicolumn{2}{|c|}{ Lithuania [2] } & \multicolumn{2}{|c|}{ Ukraine [2] } & \multicolumn{2}{|c|}{ Central Russia [2] } \\
\hline & Md & Range & Md & Range & Md & Range \\
\hline $\mathbf{N a}$ & - & - & - & - & - & - \\
\hline Cl & - & - & - & - & - & - \\
\hline $\mathbf{K}$ & - & - & - & - & - & - \\
\hline $\mathbf{C a}$ & - & - & - & - & - & - \\
\hline Sc & - & - & - & - & - & - \\
\hline $\mathbf{V}$ & 3.44 & $1.9-54.5$ & 1.29 & $0.39-4.32$ & 3.28 & $0.34-62.30$ \\
\hline $\mathrm{Cr}$ & 1.27 & $0.44-4.73$ & 1.50 & $0.46-4.38$ & 1.45 & $0.43-27.70$ \\
\hline Mn & - & - & - & - & - & - \\
\hline $\mathbf{F e}$ & 623 & $291-2820$ & 313 & $66-1320$ & 616 & $68-19600$ \\
\hline Co & - & - & - & - & - & - \\
\hline $\mathbf{N i}$ & 1.36 & $0.75-7.08$ & 2.06 & $0.72-7.05$ & 1.99 & $0.80-21.60$ \\
\hline $\mathbf{C u}$ & 6.45 & $3.7-12.3$ & 7.3 & $3.7-48.8$ & 6.5 & $3.3-35.5$ \\
\hline Zn & 34.5 & $18-87$ & 29 & $12-107$ & 35 & 13-104 \\
\hline As & 0.32 & $0.13-1.43$ & 0.24 & $0.06-0.67$ & 0.24 & $0.05-2.98$ \\
\hline Se & - & - & - & - & - & - \\
\hline $\mathrm{Br}$ & - & - & - & - & - & - \\
\hline $\mathbf{R b}$ & - & - & - & - & - & - \\
\hline $\mathbf{S r}$ & - & - & - & - & - & - \\
\hline Mo & - & - & - & - & - & - \\
\hline Cd & 0.15 & $0.09-0.31$ & 0.29 & $0.10-2.91$ & 0.23 & $0.11-1.22$ \\
\hline Sb & - & - & - & - & - & - \\
\hline I & - & - & - & - & - & - \\
\hline Cs & - & - & - & - & - & - \\
\hline $\mathbf{B a}$ & - & - & - & - & - & - \\
\hline La & - & - & - & - & - & - \\
\hline $\mathrm{Ce}$ & - & - & - & - & - & - \\
\hline $\mathbf{W}$ & - & - & - & - & - & - \\
\hline $\mathbf{P b}$ & 8.25 & $3.75-22.60$ & 6.8 & $2.3-32.6$ & 7.4 & $2.1-18.5$ \\
\hline Th & - & - & - & - & - & - \\
\hline $\mathbf{U}$ & - & - & - & - & - & - \\
\hline
\end{tabular}


The comparison made with data from the European moss study [2, 3] are quite favorable for Belarus. Examples of an approximate ranking of the atmospheric environment of Belarus relative to other countries for the $\mathrm{As}, \mathrm{Cr}, \mathrm{Ni}$ and $\mathrm{V}$ are given in Figure 4 for the survey 2005/2006 and in Figure 5 for the survey 2010/2011. The reviews of results from European countries show that for most elements concentration are low. Also for some elements, maps were made in the European concentration scale. As it is seen from Figure 5 territory of the country has very low pollution levels. However, despite the fact the territory of the Republic of Belarus is not so polluted as in other European countries it also has local polluted areas. We found out few spots at the studied area. One between Minsk and Zhodino cities - centers of heavy engineering industry. In this place, high concentrations of $\mathrm{Co}, \mathrm{Fe}, \mathrm{Zn}$ and $\mathrm{Sb}$ are observed. Co is typical element for the metal-processing industry, nonferrous smelters [16], burning of fossil fuels [17]. Sb is usually observed in the air near smelters and urban areas (because of the combustion and waste incineration) [18]. Source of the $\mathrm{Zn}$ and $\mathrm{Fe}$ emission is metals industry $[3,16]$. In addition, zinc could come from multiple sources, such as vehicle emissions [19], oil industries, coal and fuel combustion, waste disposal and incineration [20]. In case of $\mathrm{Sb}$ and $\mathrm{Zn}$, some authors reported that tire rubber abrasion and brakes could be sources of these elements in the air near high-traffic zones [21, 22]. Near Zhlobin city are founded Sb, Fe with higher concentrations. There is situated the Belarussian iron and steel plant. $\mathrm{Sb}$ and $\mathrm{Br}$ also have high concentrations near paintwork plants: in Lida, Grodno, Dzerzhinsk.

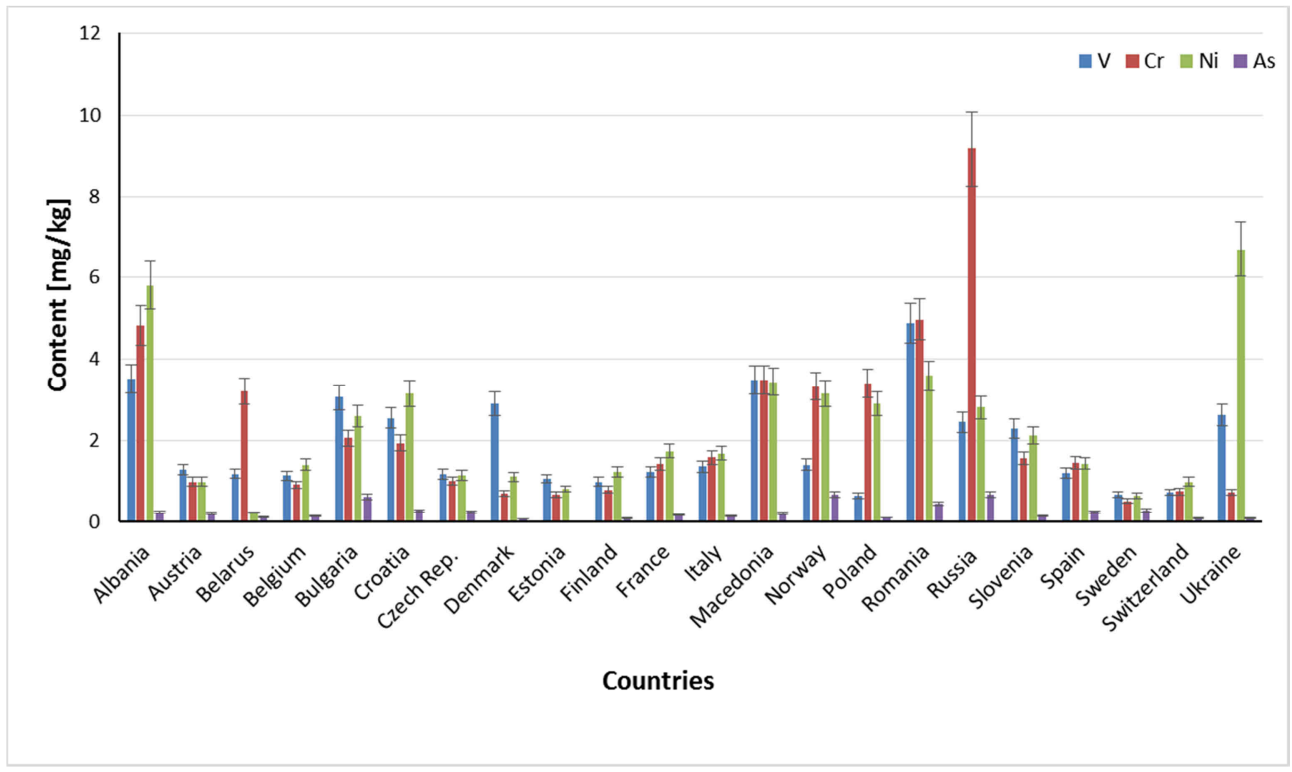

Fig. 4. Median concentrations for V, Cr, Ni, As, European Atlas - 2010/2011

In addition, we expected to find some spots of $\mathrm{Ni}$ and $\mathrm{V}$ in the northern part of the Republic of Belarus because these elements are typical for the petroleum refining and heavy oil combustion [3, 23, 24]. These elements have different distribution around the 
source, e.g. for $\mathrm{Ni}$ the relevance of urban land use within a radius of $5 \mathrm{~km}$ might be connected to local industrial emission sources, for $\mathrm{V}$ it is large radius of 75-100 km [25].

However, our results (Fig. 5) showed that petroleum-refining plant located in this region did not influence on the concentration of these elements in moss.
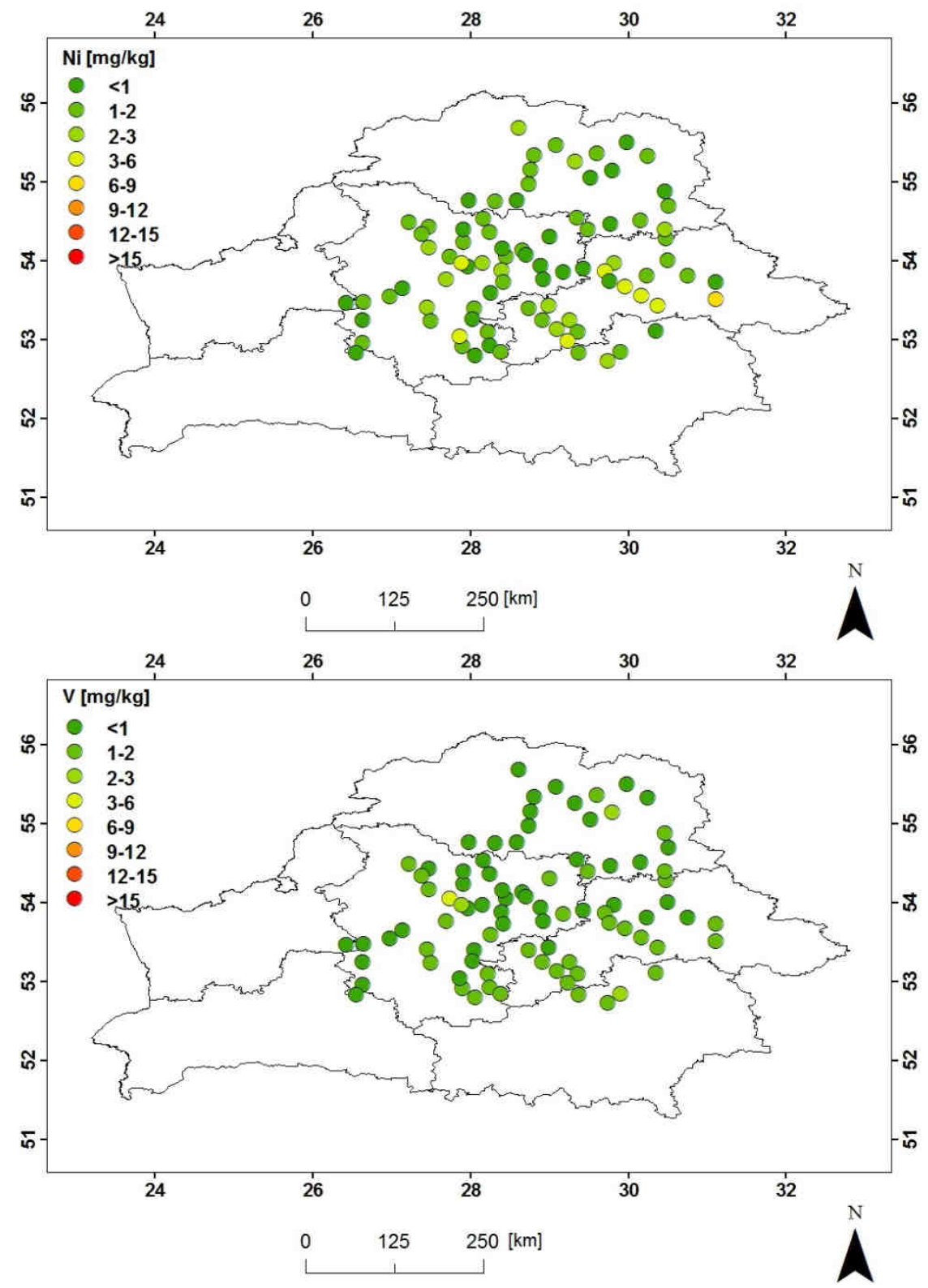

Fig. 5. Geographical distribution of $\mathrm{Ni}$ and $\mathrm{V}$ 


\section{Conclusions}

The moss biomonitoring technique was applied on the territory of Belarus at the third time. During this ten-year research, we study all Belarusian regions and create convenient sample net for the next moss survey. In comparison with other European countries, median concentrations of elements in Belarus are low. It is easy to explain, because in Belarus industry is not so developed as in nearby countries, we have not extractive and processing industry. Deposition levels for some elements in Belarus are comparable with Norwegian data but we reveal some polluted areas. In thus areas, the main pollution sources could be tractor plant in Minsk, engineering plant in Zhodino, farming, paintworks plants, iron and steel plant. In addition, we did not see any influence of the transboundary pollution in the central part of Belarus from neighboring countries. Still it is important to continue monitoring heavy metal deposition in order to see long-term trends and to study transboundary influence close to the borders with neighboring countries.

\section{Acknowledgements}

The authors would like to thank S. Pavlov and T. Ostrovnaya for the experiment part at the NAA department in JINR.

\section{References}

[1] Steinnes E, Uggerud HTh, Pfaffhuber KA, Berg T. Atmospheric deposition of heavy metals in Norway, National moss survey 2015. Norwegian Environmental Agency. 2016; M-594:57. ISBN 9788242528599, https://ntnuopen.ntnu.no/ntnu-xmlui/bitstream/handle/11250/2435067/28-2016Atmospheric+deposition+of+heavy+metals+in+Norway-HTU-KAP.pdf?sequence $=1$.

[2] European Atlas: Spatial and Temporal Trends in Heavy Metal Accumulation in Mosses in Europe (1990-2005). United Kingdom: UNECE ICP Vegetation; 2008. ISBN 978185531239-5.

[3] Harmens H, Norris D, Mills G, and the participants of the moss survey. Heavy metals and nitrogen in mosses: spatial patterns in 2010/2011 and long-term temporal trends in Europe. Bangor, UK: ICP Vegetation Programme Coordination Centre, Centre for Ecology and Hydrology; 2013. ISBN 9781906698386.

[4] Harmens H, Mills G, Hayes F, Norris DA, Sharps K. Twenty eight years of ICP Vegetation: an overview of its activities. Annali di Botanica. 2015;5:31-43. DOI: 10.4462/annbotrm-13064.

[5] http://nasb.gov.by/rus/publications/ecobull/index.php (accessed 06/03/2018).

[6] Harmens H, Frontasyeva MV. Heavy metals, nitrogen and POPs in European mosses: 2015 survey. 1st ed. Bangor, UK: ICP Vegetation Programme Coordination Centre, CEH; 2014. http://icpvegetation.ceh.ac.uk/ publications/documents/MossmonitoringMANUAL-2015-17.07.14.pdf (accessed 06/03/2018).

[7] Frontasyeva MV. Neutron activation analysis for the Life Sciences. A review. Ph of Particles and Nuclei. 2011;42(2):332-378. DOI: 10.1134/S1063779611020043.

[8] Pavlov SS, Dmitriev AY, Frontasyeva MV. Automation system for neutron activation analysis at the reactor IBR-2, Frank Laboratory of Neutron Physics, Joint Institute for Nuclear Research, Dubna, Russia. J of Radioanalyt Nucl Chem. 2016;309:27-38. DOI: 10.1007/s10967-016-4864-8.

[9] Aleksiayenak YuV, Frontasyeva MV, Ostrovnaya TM, Okina OI. Mietod mchov-biomonitorov NAA I AAS $\mathrm{v}$ issledovanii vozdushnych zagryaznenyi Belarusi (Moss biomonitoring technique, NAA and AAS in studying air pollution in Belarus). Problems of Regional Ecology. 2015;4:126-134. http://www.ecoregion.ru/annot/pre-N4-2015.pdf.

[10] Korzekwa S, Pankratova Yu, Frontasyeva MV. Air pollution studies in Opole region, Poland, using the moss biomonitoring technique and neutron activation analysis. Ecol Chem Eng A. 2007;1:43-51. http://tchie.uni.opole.pl/ecoproc07/key/Korzekwa_07.pdf.

[11] Steinnes E. Atmospheric Deposition of Heavy Metals in Norway. Nation-Wide Survey in 2005. State Program for Pollution Monitoring. Report 980/2007. Norwegian State Pollution Control Authority. Oslo; 2007. [In Norwegian]. ISBN 9788276553031.

[12] Harmens H, Norris D, Sharps K, Mills G, Alber R, Aleksiayenak Y et al. Heavy metal and nitrogen concentrations in mosses are declining across Europe whilst some "hotspots" remain in 2010. Environ Pollution. 2015;200:93-104. DOI: 10.1016/j.envpol.2015.01.036. 
[13] Travnikov O, Ilyin I, Rozovskaya O, Varygina M, Aas W, Uggerud HT et al. Long-term Changes of Heavy Metal Transboundary Pollution of the Environment (1990-2010). EMEP Status Report 2/2012. http://en.msceast.org/reports/2_2012.pdf.

[14] Frontasyeva MV, Steinnes E. Marine gradients of halogens in moss studied by epithermal neutron activation analysis. J Radioanal Nucl Chem. 2004;261:101-106. DOI: 10.1023/B:JRNC.0000030941.78117.77.

[15] Fifield FW, Haines PJ. Environmental Analytical Chemistry. 2nd ed. London: Blackie Academic \& Professional; 2000. ISBN 9780632053834.

[16] Kabata-Pendias A. Trace Elements in Soils and Plants. Boca Raton: CRC Press; 2011. ISBN 9781420093681.

[17] Kim JH, Gibb JH, Howe PD. Concise International Chemical Assessment Document 69. Geneva: World Health Organization; 2006. https://www.who.int/ipcs/publications/cicad/cicad69\%20.pdf.

[18] Xia L, Gao Y. Characterization of trace elements in PM2.5 aerosols in the vicinity of highways in northeast New Jersey in the U.S. east coast. Atmos Pollut Res. 2011;2(1):34-44, DOI: 10.5094/APR.2011.005.

[19] Bencharif-Madani F, Ali-Khodja H, Kemmouche A, Terrouche A, Lokorai K, Naidja L, et al. Mass concentrations, seasonal variations, chemical compositions and element sources of PM10 at an urban site in Constantine, northeast Algeria, J Geochem Explor. 2019:206:106356. DOI: 10.1016/j.gexplo.2019.106356.

[20] Elements and their Compounds in the Environment. 2nd ed. Weinheim: WILEY-VCH Verlag GmbH \& Co.KGaA; 2004. ISBN 3527304592, DOI: 10.1002/9783527619634.

[21] Pacyna JM, Pacyna EG. An assessment of global and regional emissions of trace metals to the atmosphere from anthropogenic sources worldwide. Environ Rev. 2001;9:269-298. DOI: 10.1139/a01-012.

[22] Adachi K, Tainosho Y. Characterization of heavy metal particles embedded in tire dust. Environ International. 2004;30:1009-1017. DOI: 10.1016/j.envint.2004.04.004.

[23] Moreno T, Querol X, Alastuey A, Rosa J, Campa AMS, Minguillón MC et al. Variations in vanadium, nickel and lanthanoid element concentrations in urban air. Sci Total Environ. 2010;408(20):4569-4579. DOI: 10.1016/j.scitotenv.2010.06.016.

[24] Dall'Osto M, Querol X, Amato F, Karanasiou A, Lucarelli F, Nava S et al. Hourly elemental concentrations in PM2.5 aerosols sampled simultaneously at urban background and road site. Atm Chem Phys. 2012;12(8):20135-20180. DOI: 10.5194/acpd-12-20135-2012.

[25] Nickel S, Schröder W, Schmalfuss R, Saathoff M. Modelling spatial patterns of correlations between concentrations of heavy metals in mosses and atmospheric deposition in 2010 across Europe. Environ Sci Eur. 2018;30(1):53. DOI: 10.1186/s12302-018-0183-8. 